Огляди літератури, оригінальні дослідження, погляд на проблему, випадок з практики, короткі повідомлення УДК 616.895.1- 616.895.6

DOI 10.11603/1811-2471.2019.v.i4.10789

\title{
КЛІНІЧНА ХАРАКТЕРИСТИКА СУЧАСНИХ ЕНДОГЕННИХ ДЕПРЕСИВНИХ РОЗЛАДІВ НА СИМПТОМАТОЛОГІЧНОМУ РІВНI
}

\author{
Вінницький національний медичний університет імені М. І. Пирогова,
}

РЕзЮмЕ. Проблема депресивних розладів є однією з найактуальніших проблем сучасної психіатрії.

Мета - вивчити особливості клінічної феноменології ендогенних депресивних розладів на сучасному етапі у гендерному та віковому аспектах.

Матеріал і методи. Клінічно обстежено 107 чоловіків і 138 жінок з встановленим діагнозом депресивного розладу за МКX-10 у період 2015-2019 років.

Результати. Встановлено, що у чоловіків питома вага усіх симптомів депресії, за винятком зниженої самооцінки, з віком збільшується: зниженого настрою з 84,2 \% у віковій групі до 30 років до 93,5 \% у віковій групі 3044 років і до 100 \% у віковій групі 45 років і старше, ангедонії - відповідно з 68,4 \% до 82,6 \% і 82,6 \%, втомлюваності з 78,9 \% до 82,6 \% і 82,6 \%, песимізму з 76,3 \% до 82,6 \% і 82,6\%, почуття провини, марності, тривоги або страху з 71,1 \% до 80,4 \% і 95,7 \%, суїцидальних думок з 52,6 \% до 63,0 \% і 78,3 \%, порушень апетиту з 47,4 \% до 67,4 \% і 78,3 \%, диссомній з 86,8 \% до 95,7\% і 95,7 \%. У жінок виявлена складна вікова динаміка: для зниженого настрою відповідно 82,4 \%, 96,2 \% і 97,1 \%, ангедонії - 86,3 \%, 88,7 \% і 82,4 \%, втомлюваності - 90,2 \%, 86,8 \% і 88,2 \%, песимізму - 86,3 \%, 84,9 \% і 88,2 \%, почуття провини, марності, тривоги або страху - 86,3 \%, 94,3 \% і 97,1 \%, зниженої самооцінки - 88,2 \%, 77,4 \% і 79,4 \%, суїцидальних думок - 68,6 \%, 62,3 \% і 82,4 \%, порушень апетиту - 76,5 \%, 75,5 \% і 85,3 \%, диссомній - 90,2 \%, 92,5 \% і 97,1\%. Між чоловіками і жінками виявлено значущі $($ р<0,05) розбіжності за показниками ангедонії, почуття провини, марності, тривоги або страху, зниженої самооцінки, порушень апетиту.

Висновки. Клінічна феноменологія депресивних розладів на симптоматичному рівні обумовлена певними гендерними та віковими відмінностями, що полягають, зокрема, в переважанні у жінок тривожної та соматовегетативної симптоматики з астено-депресивними проявами, а у чоловіків проявляється рівномірною динамікою погіршення з віком за всіма основними симптомами депресії.

КлючОВІ СлОВА: ендогенні депресивні розлади; клінічна феноменологія.

Вступ. Депресивні розлади є однією з найактуальніших проблем сучасної психіатричної науки і практики $[1,2]$. Депресивні розлади тісно асоційовані з глибокими змінами психічної сфери, аутоагресивною поведінкою і значними порушеннями соціальної адаптації хворих та їх мікросоціального оточення, включаючи деформацію гомеостазу сімейної системи $[3,4]$. Дослідженнями останніх років доведено наявність патоморфозу депресивних розладів, що поширюється, зокрема, на гендерні, вікові, соціальні характеристики, а також на клінічні прояви захворювання $[5,6]$. У зв'язку з цим важливого значення для розуміння клініко-патогенетичних закономірностей патоморфозу депресивних розладів набуває дослідження їх клінічної феноменології [7].

Метою дослідження було вивчити особливості клінічної феноменології ендогенних депресивних розладів на сучасному етапі у гендерному та віковому аспектах.

Матеріал і методи дослідження. 3 дотриманням принципів біомедичної етики на підставі інформованої згоди нами було клінічно обстежено 107 чоловіків і 138 жінок, які зверталися за психіатричною допомогою до Вінницької обласної психоневрологічної лікарні імені акад. О. І. Ющенка протягом 2015-2019 років. Критерієм включен- ня до дослідження було встановлення діагнозу депресивного розладу відповідно до критеріїв MKX-10 (коди F31.3, F31.4, F32.0, F32.1, F32.2, F33.0, F33.1, F33.2) [8]. Середній вік обстежених хворих склав $33,6 \pm 11,2$ років (медіана 33,0 років, інтерквартильний діапазон 22,0-42,0 років), чоловіків$34,2 \pm 11,1$ років (34,0 років, $23,0-42,0$ років), жінок$33,2 \pm 11,4$ років ( 33,0 років, $22,0-41,0$ років), $p>0,05$. Середня тривалість захворювання на момент обстеження склала $5,0 \pm 5,6$ років ( 4,0 років; $0,0-8,0$ років), чоловіків - 5,7 $\pm 5,8$ років (4,0 років, 0,0-9,0 років), жінок $-4,5 \pm 5,4$ роки (2,0 років; $0,0-7,0$ років), p>0,05. Усі обстежені були поділені на групи залежно від віку на момент обстеження: до 30 років (38 чоловіків, група 41; 51 жінка, група ж1); 30-44 роки (46 чоловіків, Ч2; 53 жінки, Ж2); 45 років і старші (23 чоловіки, 43; 34 жінки, Ж3). У дослідженні використано клініко-анамнестичний, соціально-демографічний, клініко-психопатологічний, статистичний методи. Статистичну обробку даних проводили за допомогою точного критерію Фішера.

Результати й обговорення. Дослідження особливостей клінічних проявів депресії на рівні симптомів у чоловіків та жінок різних вікових груп дозволило виявити у чоловіків тенденцію до збільшення питомої ваги майже усіх симптомів 3 віком (табл. 1). 
Огляди літератури, оригінальні дослідження, погляд на проблему, випадок з практики, короткі повідомлення

Таблиця 1. Структура клінічної симптоматики депресивних розладів відповідно до критеріїв MKX-10 у чоловіків різних вікових груп

\begin{tabular}{|c|c|c|c|c|c|c|c|c|}
\hline \multirow{3}{*}{ Симптом } & \multicolumn{8}{|c|}{ Групи } \\
\hline & \multicolumn{2}{|c|}{41} & \multicolumn{2}{|c|}{42} & \multicolumn{2}{|c|}{43} & \multicolumn{2}{|c|}{ Разом } \\
\hline & a6c. & $\%$ & a6c. & $\%$ & a6c. & $\%$ & a6c. & $\%$ \\
\hline Знижений настрій & 32 & 84,2 & 43 & 93,5 & 23 & 100 & 98 & 91,6 \\
\hline Ангедонія & 26 & 68,4 & 38 & 82,6 & 19 & 82,6 & 83 & 77,6 \\
\hline Втомлюваність & 30 & 78,9 & 38 & 82,6 & 19 & 82,6 & 87 & 81,3 \\
\hline Песимізм & 29 & 76,3 & 38 & 82,6 & 19 & 82,6 & 86 & 80,4 \\
\hline Почуття провини, марності, тривоги або страху & 27 & 71,1 & 37 & 80,4 & 22 & 95,7 & 86 & 80,4 \\
\hline Занижена самооцінка & 27 & 71,1 & 38 & 82,6 & 16 & 69,6 & 81 & 75,7 \\
\hline Думки про смерть або самогубство & 20 & 52,6 & 29 & 63,0 & 18 & 78,3 & 67 & 62,6 \\
\hline Нестабільний апетит, зміна ваги & 18 & 47,4 & 31 & 67,4 & 18 & 78,3 & 67 & 62,6 \\
\hline Диссомнії & 33 & 86,8 & 44 & 95,7 & 22 & 95,7 & 99 & 92,5 \\
\hline
\end{tabular}

3 основних симптомів депресії виявлено збільшення питомої ваги пацієнтів зі зниженим настроєм, ангедонією, вираженою втомлюваністю. Для додаткової симптоматики в цілому зберігається та ж тенденція до зростання поширеності симптому з віком, що й для основної симптоматики, за винятком зниженої самооцінки, питома вага якої є найбільшою у групі Ч2, і найменшою у групі ЧЗ.

Натомість, у жінок з основної симптоматики чітку динаміку погіршення з віком виявили лише прояви зниженого настрою; прояви ангедонії у групі ж2 виявлені дещо частіше, ніж у Ж1, а у групі ж3 їх поширеність незначно зменшується. Прояви підвищеної втомлюваності найчастіше виявлені у групі Ж1, у групі Ж2 вони дещо зменшуються, а у групі Ж3 - незначуще збільшуються. Для почуття провини, марності, тривоги або страху, а також для проявів диссомній була виявлена тенденція до незначущого збільшення з віком; для песимізму, суїцидальних думок і порушень апетиту - тенденція до найбільшого поширення у старшій віковій групі, меншого -у молодшій, і найменшого - у середній віковій групі; а для заниженої самооцінки - поступове зменшення питомої ваги симптому з віком (табл. 2).

Таблиця 2. Структура клінічної симптоматики депресивних розладів відповідно до критеріїв МКX-10 у жінок різних вікових груп (Ж)

\begin{tabular}{|c|c|c|c|c|c|c|c|c|}
\hline \multirow{3}{*}{ Симптом } & \multicolumn{8}{|c|}{ Групи } \\
\hline & \multicolumn{2}{|c|}{ ж1 } & \multicolumn{2}{|c|}{ ж2 } & \multicolumn{2}{|c|}{ ж3 } & \multicolumn{2}{|c|}{ Разом } \\
\hline & a6c. & $\%$ & a6c. & $\%$ & a6c. & $\%$ & a6c. & $\%$ \\
\hline Знижений настрій & 42 & 82,4 & 51 & 96,2 & 33 & 97,1 & 126 & 91,3 \\
\hline Ангедонія & 44 & 86,3 & 47 & 88,7 & 28 & 82,4 & 119 & 86,2 \\
\hline Втомлюваність & 46 & 90,2 & 46 & 86,8 & 30 & 88,2 & 122 & 88,4 \\
\hline Песимізм & 44 & 86,3 & 45 & 84,9 & 30 & 88,2 & 119 & 86,2 \\
\hline Почуття провини, марності, тривоги або страху & 44 & 86,3 & 50 & 94,3 & 33 & 97,1 & 127 & 92,0 \\
\hline Знижена самооцінка & 45 & 88,2 & 41 & 77,4 & 27 & 79,4 & 113 & 81,9 \\
\hline Думки про смерть або самогубство & 35 & 68,6 & 33 & 62,3 & 28 & 82,4 & 96 & 69,6 \\
\hline Нестабільний апетит, зміна ваги & 39 & 76,5 & 40 & 75,5 & 29 & 85,3 & 108 & 78,3 \\
\hline Диссомнії & 46 & 90,2 & 49 & 92,5 & 33 & 97,1 & 128 & 92,8 \\
\hline
\end{tabular}

Порівняння поширеності різних симптомів у чоловіків і у жінок виявило значущі розбіжності для ангедонії при порівнянні груп Ч1 і 1 ( $<<0,05)$, почуття провини, марності, тривоги або страху груп 42 і Ж2 $(p<0,05)$ та чоловіків і жінок в цілому $(p<0,01)$, зниженої самооцінки - груп 41 і ж1, Ч2 і ж2 (p<0,05), нестабільного апетиту і зміни ваги груп Ч1 і ж1 (p<0,05), та чоловіків і жінок в цілому $(p<0,01)$ (табл. 3).
Одержані нами дані узгоджуються з даними власних досліджень та досліджень інших авторів щодо наявності певних гендерних та вікових відмінностей, клінічного патоморфозу депресивних розладів, зокрема, більшої поширеності тривожно-депресивної і соматовегетативної симптоматики у жінок, а також щодо зменшення питомої ваги класичних вітальних форм депресії при збільшенні астенічних, апатичних і тривожних форм. 
Огляди літератури, оригінальні дослідження, погляд на проблему, випадок з практики, короткі повідомлення Таблиця 3. Рівень статистичної значущості розбіжностей (р) при порівнянні груп

\begin{tabular}{|c|c|c|c|c|c|c|c|c|c|c|}
\hline \multirow[b]{2}{*}{ Симптом } & \multicolumn{10}{|c|}{ Групи, що порівнюються } \\
\hline & $\begin{array}{l}41 \text { vs } \\
42\end{array}$ & $\begin{array}{l}41 \text { vs } \\
43\end{array}$ & $\begin{array}{l}42 \text { vs } \\
43\end{array}$ & $\begin{array}{l}\text { *1 vs } \\
\text { ж2 }\end{array}$ & $\begin{array}{l}\text { ж1 vs } \\
\text { *3 }\end{array}$ & $\begin{array}{l}\text { ж2 vs } \\
\text { ж3 }\end{array}$ & $\begin{array}{l}\text { ч1 vs } \\
\text { *1 }\end{array}$ & $\begin{array}{l}42 \text { vs } \\
\text { Ж2 }\end{array}$ & $\begin{array}{l}43 \text { vs } \\
\text { ж3 }\end{array}$ & ५ vs $Ж$ \\
\hline Знижений настрій & 0,156 & 0,050 & 0,290 & 0,022 & 0,037 & 0,663 & 0,526 & 0,433 & 0,597 & 0,563 \\
\hline Ангедонія & 0,104 & 0,179 & 0,640 & 0,470 & 0,422 & 0,299 & 0,039 & 0,282 & 0,634 & 0,055 \\
\hline Втомлюваність & 0,440 & 0,500 & 0,640 & 0,408 & 0,521 & 0,560 & 0,119 & 0,382 & 0,410 & 0,085 \\
\hline Песимізм & 0,328 & 0,404 & 0,640 & 0,533 & 0,533 & 0,459 & 0,176 & 0,484 & 0,410 & 0,146 \\
\hline $\begin{array}{l}\text { Почуття провини, марності, } \\
\text { тривоги або страху }\end{array}$ & 0,227 & 0,017 & 0,087 & 0,144 & 0,095 & 0,489 & 0,067 & 0,035 & 0,649 & 0,006 \\
\hline Знижена самооцінка & 0,159 & 0,562 & 0,176 & 0,113 & 0,211 & 0,520 & 0,039 & 0,347 & 0,295 & 0,153 \\
\hline $\begin{array}{l}\text { Думки про смерть або } \\
\text { самогубство }\end{array}$ & 0,229 & 0,040 & 0,158 & 0,317 & 0,122 & 0,038 & 0,094 & 0,552 & 0,478 & 0,157 \\
\hline $\begin{array}{l}\text { Нестабільний апетит, зміна } \\
\text { ваги }\end{array}$ & 0,051 & 0,016 & 0,259 & 0,544 & 0,238 & 0,204 & 0,005 & 0,252 & 0,366 & 0,006 \\
\hline Диссомнії & 0,146 & 0,258 & 0,744 & 0,475 & 0,224 & 0,347 & 0,433 & 0,409 & 0,649 & 0,567 \\
\hline
\end{tabular}

Дані нашого дослідження можуть бути використані при розробці лікувально-реабілітаційних заходів для хворих на депресивні розлади, а також для профілактики різних форм депресій.

Висновки. 1. Клінічна феноменологія депресивних розладів на симптоматичному рівні обумовлена певними гендерними та віковими відмінностями.

2. Клініко-симптоматичні особливості депресивних розладів у жінок полягають у значущому переважанні тривожної та соматовегетативної симптоматики, що асоціюється з астено-депресивними проявами.

3. Учоловіків депресивна симптоматика рівномірно посилюється з віком за рахунок зниженого настрою, ангедонії, втомлюваності, песимізму, почуття провини, марності, тривоги або страху, суїцидальних думок, порушень апетиту та диссомній.

Перспективи подальших наукових досліджень пов'язані із розробкою на підставі одержаних даних персоніфікованих лікувально-профілактичних та реабілітаційних заходів.

\section{ЛІТЕРАТУРА}

1. Fekadu N. Major depressive disorder: pathophysioogy and clinical management / N. Fekadu, W. Shibeshi, E. Engidawork / N. Fekadu // Journal of Depression and Anxiety. - 2017. - Vol. 6 (1). - P. 255-257.

2. Cleare A. Evidence-based guidelines for treating depressive disorders with antidepressants: a revision of the 2008 British Association for Psychopharmacology guidelines / A. Cleare, C. M. Pariante, A. H. Young // Journal of Psychopharmacology. - 2015. - Vol. 29 (5). - P. 459-525.

3. Pshuk N. G. Introducing system of psychotherapeutic intervention for family caregivers of patients with endogenous mental disorders / N. G. Pshuk, L. V. Stukan, A. O. Kaminska // Wiadomosci Lekarskie. - 2018. - Vol. 71 (5). - P. 980-985.

4. Kessing L. V. Does cognitive dysfunction in bipolar disorder qualify as a diagnostic intermediate phenotype? / L. V. Kessing, K. Miskowiak // Frontiers in Psychiatry. 2018. - Vol. 9. - P. 490.

5. Rakhman L. V. Clinical and therapeutic levels of pathomorphosis of treatment-resistant depression / L. V. Rakhman, M. V. Markova // Медицинская психология. - 2014. № 1. - P. 36-40.
6. Скрипніков А. М. Віковий патоморфоз рекурентних депресивних розладів / А. М. Скрипніков, Л. О. Герасименко, К. В. Гринь // Світ медицини та біології. - 2016. - № 4 (58). - С. 64-66.

7. Markova M. Contents and efficiency measures of psychoeducation in rehabilitation system of patients with bipolar affective disorder / M. Markova, O. Rezunenko, H. Kozhyna // Journal of Education, Health end Sport. 2017. - Vol. 7. - P. 711-715.

8. International Statistical Classification of Diseases and Related Health Problems 10th Revision (ICD-10). - Geneva : World Health Organization, 1994.

9. Венгер О. П. Гендерно-вікові та соціально-медичні особливості емігрантів та реемігрантів, хворих на депресивні розлади / О. П. Венгер // Вісник наукових досліджень. - 2016. - № 1. - С. 88-91.

10. Венгер О. П. Особливості клінічної симптоматики депресивних розладів у емігрантів та реемігрантів / О. П. Венгер // Психічне здоров' я. - 2015. - № 2. С. 3-8. 
Огляди літератури, оригінальні дослідження, погляд на проблему, випадок з практики, короткі повідомлення REFERENCES

1. Fekadu, N., Shibeshi, W., \& Engidawork, E. (2017). Major depressive disorder: pathophysiology and clinical management. Journal of Depression and Anxiety, 6 (1), 255257.

2. Cleare, A., Pariante, C.M., \& Young, A.H. (2015). Evidence-based guidelines for treating depressive disorders with antidepressants: a revision of the 2008 British Association for Psychopharmacology guidelines. Journal of Psychopharmacology, 29 (5), 459-525.

3. Pshuk, N.G., Stukan, L.V., \& Kaminska, A.O. (2018). Introducing system of psychotherapeutic intervention for family caregivers of patients with endogenous mental disorders. Wiadomosci Lekarskie, 71 (5), 980-985.

4. Kessing, L.V., \& Miskowiak, K. (2018). Does cognitive dysfunction in bipolar disorder qualify as a diagnostic intermediate phenotype? Frontiers in Psychiatry, 9, 490.

5. Rakhman, L.V., \& Markova, M.V. (2014). Clinical and therapeutic levels of pathomorphosis of treatment-resistant depression. Meditsinskaya psikhologiya - Medical Psychology, 1, 36-40.

6. Skrypnikov, A.M., Herasimenko, L.O., \& Hryn, K.V. (2016). Vikovyi patomorfoz rekurrentnykh depressyvnykh

rozladiv [Age pathomorphosis recurrent depressive disorders]. Svit medytsyny ta biolohii - World of Medicine and Biology, 4 (58), 64-66 [in Ukrainian].

7. Markova, M., Rezunenko, O., \& Kozhyna, H. (2017). Contents and efficiency measures of psychoeducation in rehabilitation system of patients with bipolar affective disorder. Journal of Education, Health end Sport, 7, 711. 715.

8. International Statistical Classification of Diseases and Related Health Problems 10th Revision (ICD-10) (1994). Geneva, World Health Organization.

9. Venher, O.P. (2016). Henderno-vikovi ta sotsialnomedychni osoblyvosti emihrantiv ta reemihrantiv, khvorykh na depresyvni rozlady [Gender-age and socio-medical features of emigrants and re-emigrants suffering from depressive disorders]. Visnyk naukovykh doslidzhen - Bulletin of Scientific Research, 1, 88-91 [in Ukrainian].

10. Venher, O.P. (2015). Osoblyvosti klinichnoi symptomatyky depresyvnykh rozladiv u emihrantiv ta reemihrantiv [Peculiarities of clinical symptomatology of depressive disorders in emigrants and re-emigrants]. Psykhichne zdorovia-Mental Health, 2, 3-8 [in Ukrainian].

\section{КЛИНИЧЕСКАЯ ХАРАКТЕРИСТИКА СОВРЕМЕННЫХ ЭНДОГЕННЫХ ДЕПРЕССИВНЫХ РАССТРОЙСТВ НА СИМПТОМАТОЛОГИЧЕСКОМ УРОВНЕ}

Винницкий национальный медицинский университет имени Н. И. Пирогово

РЕЗЮМЕ. Проблема депрессивных расстройств является одной из наиболее актуальных проблем современной психиатрии.

Цель - изучить особенности клинической феноменологии эндогенных депрессивных расстройств на современном этапе в гендерном и возрастном аспектах.

Материалы и методы. Клинически обследованы 107 мужчин и 138 женщин с установленным диагнозом депрессивного расстройства по МКБ-10 в период 2015-2019 годов.

Результаты. Установлено, что у мужчин удельный вес всех симптомов депрессии, за исключением заниженной самооценки, с возрастом увеличивается: сниженного настроения с 84,2 \% в возрастной группе до 30 лет до 93,5 \% в возрастной группе 30-44 лет и до $100 \%$ в возрастной группе 45 лет и старше, ангедонии - соответственно с 68,4 \% до 82,6 \% и 82,6 \%, утомляемости с 78,9\% до 82,6 \% и 82,6 \%, пессимизма с 76,3 \% до 82,6 \% и 82,6 \%, чувства вины, бесполезности, тревоги или страха с 71,1 \% до 80,4 \% и 95,7 \%, суицидальных мыслей с 52,6 \% до 63,0 \% и 78,3 \%, нарушений аппетита с 47,4 \% до 67,4 \% и 78,3 \%, диссомний с 86,8 \% до 95,7 \% и 95,7 \%. У женщин выявлена сложная возрастная динамика: для сниженного настроения - соответственно 82,4 \%, 96,2 \% и 97,1 \%, ангедонии $-86,3 \%, 88,7 \%$ и 82,4 \%, утомляемости - 90,2 \%, 86,8 \% и 88,2 \%, пессимизма - 86,3 \%, 84,9 \% и 88,2 \%, чувства вины, бесполезности, тревоги или страха - 86,3\%, 94,3 \% и 97,1\%, заниженной самооценки - 88,2 \%, 77,4 \% и 79,4 \%, суицидальных мыслей - 68,6 \%, 62,3 \% и 82,4 \%, нарушений аппетита - 76,5%, 75,5 \% и 85,3 \%, диссомний $90,2 \%, 92,5 \%$ и 97,1 \%. Между мужчинами и женщинами обнаружены значимые $(p<0,05)$ различия для ангедонии, чувства вины, бесполезности, тревоги или страха, заниженной самооценки, нарушений аппетита.

Выводы. Клиническая феноменология депрессивных расстройств на симптоматическом уровне обусловлена определенными гендерными и возрастными различиями, состоящими, в частности, в преобладании у женщин тревожной и соматовегетативной симптоматики с астено-депрессивными проявлениями, а у мужчин - равномерной динамикой ухудшения с возрастом по всем основным симптомам депрессии.

КЛЮЧЕВЫЕ СЛОВА: эндогенные депрессивные расстройства; клиническая феноменология. 


\title{
CLINICAL CHARACTERISTICS OF MODERN ENDOGENOUS DEPRESSIVE DISORDERS
} AT THE SYMPTOMATOLOGICAL LEVEL

\author{
๑O. O. Belov, N. G. Pshuk
}

\section{Pyrohov Vinnytsia National Medical University}

SUMMARY. Problem of depressive disorders is one of the actual problems in modern psychiatry.

The aim - to investigate the clinical phenomenology of endogenous depressive disorders at the present stage in gender and age aspects.

Material and Methods. We have clinically examined 107 men and 138 women diagnosed with depressive disorder in $\mathrm{MCH}-10$ in the period 2015-2019.

Results and Discussion. In men, the proportion of all depressive symptoms, with the exception of lowered selfesteem, is found to increase with age: lowered mood from $84.2 \%$ in 30-44 age group to $93.5 \%$ in $30-44$ age group and up to $100 \%$ in age group 45 years and older, anhedonia - respectively from $68.4 \%$ to $82.6 \%$ and $82.6 \%$, fatigue from $78.9 \%$ to $82.6 \%$ and $82.6 \%$, pessimism from $76.3 \%$ to $82.6 \%$ and $82.6 \%$, feelings of guilt, futility, anxiety or fear from $71.1 \%$ to $80.4 \%$ and $95.7 \%$, suicidal thoughts from $52.6 \%$ to $63.0 \%$ and $78.3 \%$, appetite disorders from $47.4 \%$ to $67.4 \%$ and $78.3 \%$, dyssomnia from $86.8 \%$ to $95.7 \%$ and $95.7 \%$. Women have a complex age dynamics: respectively $82.4 \%, 96.2 \%$ and $97.1 \%$ for lowered mood, $86.3 \%, 88.7 \%$ and $82.4 \%$ for anhedonia, and $90.2 \%, 86.8 \%$ and $88.2 \%$ for fatigue, $86.3 \%, 84.9 \%$ and $88.2 \%$ for pessimism, $86.3 \%, 94.3 \%$ and $97.1 \%$ for guilt, futility, anxiety or fear, $88.2 \%$, $77.4 \%$ and $79.4 \%$ for low self-esteem, $68.6 \%, 62.3 \%$ and $82.4 \%$ for suicidal thoughts, $76.5 \%, 75.5 \%$ and $85.3 \%$ for appetite disorders, $90.2 \%, 92.5 \%$ and $97.1 \%$ for dyssomnia. Significant $(p<0.05)$ differences between men and women were identified for anhedonia, guilt, futility, anxiety or fear, low self-esteem, and appetite disorders.

Conclusions. Clinical phenomenology of depressive disorders at the symptomatic level is caused by certain gender and age differences, which are, in particular, in the predominance of anxiety and somatovegetative symptoms in women with asthenic-depressive manifestations, and in men with uniform dynamics of worsening by all main depression symptoms.

KEY WORDS: endogenous depressive disorders; clinical phenomenology. 